\title{
Carbonate stability in the reduced lower mantle
}

2 Authors: Susannah M. Dorfman ${ }^{1,2 *}$, James Badro ${ }^{3,1}$, Farhang Nabiei ${ }^{1}$, Vitali B. Prakapenka ${ }^{4}$, Marco Cantoni ${ }^{5}$, Philippe Gillet ${ }^{1}$

4 Affiliations:

$5{ }^{1}$ Earth and Planetary Science Laboratory, Ecole polytechnique fédérale de Lausanne, Station 3, 6 CH-1015 Lausanne, Switzerland.

$7 \quad{ }^{2}$ Department of Earth and Environmental Sciences, Michigan State University, East Lansing, MI, 8 48824, USA.

9 Institut de Physique du Globe de Paris, Sorbonne Paris Cité, UMR CNRS 7154, 75005 Paris, 10 France.

$11{ }^{4}$ Center for Advanced Radiation Sources, University of Chicago, Argonne, IL 60439, USA.

$12{ }^{5}$ Centre Interdisciplinaire de Microscopie Electronique, Ecole polytechnique fédérale de 13 Lausanne, Station 12, 1015 Lausanne, Switzerland.

$14 *$ Correspondence to: dorfman3@msu.edu 


\section{Abstract}

Carbonate minerals are important hosts of carbon in the crust and mantle with a key role

19 in the transport and storage of carbon in Earth's deep interior over the history of the planet.

20 Whether subducted carbonates efficiently melt and break down due to interactions with reduced

21 phases or are preserved to great depths and ultimately reach the core-mantle boundary remains

22 controversial. In this study, experiments in the laser-heated diamond anvil cell (LHDAC) on

23 layered samples of dolomite $(\mathrm{Mg}, \mathrm{Ca}) \mathrm{CO}_{3}$ and iron at pressure and temperature conditions

24 reaching those of the deep lower mantle show that carbon-iron redox interactions destabilize the

$25 \mathrm{MgCO}_{3}$ component, producing a mixture of diamond, $\mathrm{Fe}_{7} \mathrm{C}_{3}$, and $(\mathrm{Mg}, \mathrm{Fe}) \mathrm{O}$. However, $\mathrm{CaCO}_{3}$ is

26 preserved, supporting its relative stability in carbonate-rich lithologies under reducing lower

27 mantle conditions. These results constrain the thermodynamic stability of redox-driven

28 breakdown of carbonates and demonstrate progress towards multiphase mantle petrology in the

29 LHDAC at conditions of the lowermost mantle.

\section{Introduction}

31 Carbonates are the major minerals responsible for transportation of carbon from the

32 Earth's surface to its deep interior. Their behavior at depth is critical to the storage capacity and

33 fluxes of the geologic carbon cycle. Recent estimates of the flux of carbon trapped in carbonate

34 minerals that reach the deep Earth range from 0.0001 to 52 megatons annually (Dasgupta and

35 Hirschmann, 2010; Kelemen and Manning, 2015). The uncertainty in this range hinges on poor

36 constraints on the budget of carbon retained by subducting slabs. Transport of carbon to at least

37 transition zone depths is demonstrated by carbonate inclusions in diamonds (e.g. Brenker et al.,

38 2007; Wang et al., 1996), but whether any carbonates remain in the lower mantle is

39 controversial. Most subducted carbon is expected to melt and/or break down and return to 
40 Earth's surface via volcanism (Dasgupta and Hirschmann, 2010; Kelemen and Manning, 2015;

41 Thomson et al., 2016). However, relatively oxidizing conditions, low temperatures, and resulting

42 slow kinetics within subducting slabs may result in transportation of carbonates magnesite,

43 siderite, calcite, and their solid solutions to great depths (Martirosyan et al., 2016). Subducted

44 carbonates in slabs that reach the base of the lower mantle will undergo multiple phase

45 transitions and encounter reducing conditions, to be finally buffered by metallic iron at or near 46 the $\mathrm{CMB}$.

47 Carbon provides key constraints on the chemical evolution of the deep Earth through its

48 role as a proxy for mantle redox conditions, as its speciation is largely governed by oxygen

49 fugacity, or $f_{\mathrm{O} 2}$ (Frost and McCammon, 2008). Evidence of deep mantle chemistry (Walter et al.,

50 2011) and redox state (Ryabchikov and Kaminsky, 2013; Smith et al., 2016) in local

51 environments of diamond formation can likely be inferred from diamond inclusions. Diamonds

52 and their inclusions indicate widely varying local $f_{02}$ (Brenker et al., 2007; Walter et al., 2011;

53 Ryabchikov and Kaminsky, 2013; Smith et al., 2016; Kaminsky, 2012), though $f_{\mathrm{O} 2}$ is expected to

54 generally decrease with mantle depth (Frost and McCammon, 2008; Rohrbach and Schmidt,

55 2011). Both isotopic evidence (e.g. Harte, 2010; Tappert et al., 2005) and carbonate inclusions in

56 diamonds (e.g. Wang et al., 1996) suggest that diamonds are (at least in part) formed by

57 reduction of subducted carbonate minerals or carbonate melts. Reduction of carbonates to

58 diamond takes place by interactions with mantle silicates (Pal'yanov et al., 2002; Stagno et al.,

59 2011, 2013, 2015) or metal (Arima et al., 2002; Siebert et al., 2005; Rouquette et al., 2008;

60 Pal'yanov et al., 2013). These redox reactions contribute to the barrier to carbonate transport to

61 the deep Earth (Rohrbach and Schmidt, 2011; Thomson et al., 2016). The key to determining the 
62 amount of oxidized carbon in the deep Earth is the dependence of both the thermodynamics and

63 the kinetics of redox reactions in carbonates on temperature, pressure, and $f_{\mathrm{O} 2}$.

Petrologic observations, experiments and computational studies on stability and

65 breakdown kinetics of carbonates have determined that magnesite is the most stable carbonate

66 phase throughout most of the mantle (e.g. Dasgupta and Hirschmann, 2010; Rohrbach and

67 Schmidt, 2011), but calcite and siderite polymorphs have also attracted interest. Relative to

68 aragonite (Spivak et al., 2011) or siderite (Tao et al., 2013), magnesite is more likely to subduct

69 to the deep mantle due to its higher melting temperature (Isshiki et al., 2004; Katsura and Ito,

70 1990; Martinez et al., 1998; Solopova et al., 2014). Melting experiments on carbonated peridotite

71 (Dasgupta and Hirschmann, 2010; Ghosh et al., 2014; Rohrbach and Schmidt, 2011) and eclogite

72 (Thomson et al., 2016) systems confirm that calcium and iron carbonate components are more

73 likely to enter a melt phase than magnesium carbonate in silicate lithologies. At sub-solidus

74 temperatures, $\mathrm{MgCO}_{3}$ is also favored in carbonate-silicate mixtures by the reaction $\mathrm{CaCO}_{3}+$

$75 \mathrm{MgSiO}_{3} \rightarrow \mathrm{MgCO}_{3}+\mathrm{CaSiO}_{3}$ at lower-mantle pressures up to $80 \mathrm{GPa}$ (Biellmann et al., 1993;

76 Seto et al., 2008). Due to its broad solid solution with siderite (Lin et al., 2012; Liu et al., 2015),

77 magnesite in the mantle will host iron. $\mathrm{An}(\mathrm{Mg}, \mathrm{Fe})$-carbonate in the lowermost mantle may have

78 mixed redox state and coexist with diamond (Boulard et al., 2012). However, both ( $\mathrm{Mg}, \mathrm{Fe}) \mathrm{CO}_{3}$

79 (Brenker et al., 2007; Kaminsky et al., 2016; Phillips and Harris, 1995; Ryabchikov and

80 Kaminsky, 2013) and $\mathrm{CaCO}_{3}$ (Brenker et al., 2007; Meyer and McCallum, 1986) have been

81 observed in inclusions in diamonds, including ultra-deep diamonds from the transition zone or

82 possibly the lower mantle (Brenker et al., 2007). These inclusions demonstrate that both

$83(\mathrm{Mg}, \mathrm{Fe}) \mathrm{CO}_{3}$ and $\mathrm{CaCO}_{3}$ may be preserved by kinetic effects within carbonate-rich sediment in

84 cold subducting slabs, consistent with slow breakdown kinetics observed in experiments at 
85 transition zone conditions (Martirosyan et al., 2016). The relative stability of $(\mathrm{Mg}, \mathrm{Fe}) \mathrm{CO}_{3}$ and

$86 \mathrm{CaCO}_{3}$ may also change at depth due to polymorphism. If $(\mathrm{Mg}, \mathrm{Fe}) \mathrm{CO}_{3}$ or $\mathrm{CaCO}_{3}$ reaches the

87 base of the lower mantle, density functional theory calculations (Oganov et al., 2008; Pickard

88 and Needs, 2015) and experiments (Boulard et al., 2011; Ono et al., 2007) suggest these

89 carbonates will transform to tetrahedrally-coordinated structures. If the transition in $\mathrm{CaCO}_{3}$

90 occurs at a shallower depth than the analogous transition in $\mathrm{MgCO}_{3}$, as predicted by Pickard and

91 Needs (2015), $\mathrm{CaCO}_{3}$ would be the denser and more energetically-favored carbonate in the deep

92 lower mantle.

93 This study examines a $\mathrm{Mg}-\mathrm{Fe}-\mathrm{Ca}$ carbonate system in the petrologic context of a

94 subducted carbonate assemblage in contact with metallic iron. Metallic iron may be present at

95 the percent level throughout the mantle (Frost et al., 2004), and the outer core provides an

96 unlimited reservoir of iron. Subducted carbonates may contact reduced core-mantle mixing

97 regions if they reach depths within $\sim 10 \mathrm{~s} \mathrm{~km}$ from the base of the mantle (Frost and McCammon,

98 2008; Otsuka and Karato, 2012). Previous studies of carbonates at lower mantle pressures have

99 investigated mineralogical stability of single phases as a function of pressure and temperature

100 alone (Isshiki et al., 2004; Solopova et al., 2014; Boulard et al., 2011; Ono et al., 2005), or used

101 mixtures of carbonates and silicates which complicate textural analysis of run products

102 (Biellmann et al., 1993; Thomson et al., 2014). In contrast, we examine reaction interfaces

103 between multiple carbonates and iron; similar previous studies have been limited to transition

104 zone conditions (Martirosyan et al., 2016; Pal'yanov et al., 2013). We determine the relative

105 stability and metastability of $\mathrm{Mg}-, \mathrm{Fe}-$, and Ca-carbonates as host phases for oxidized carbon

106 storage in the lower mantle. 


\section{Methods}

To bring experimental petrology of carbonates to the Mbar pressures and 1000s K

109 temperatures of the core-mantle boundary, experiments must be miniaturized: sample geometry

110 must be controlled within the $\sim 50 \times 50 \times 10$-micron chamber of the laser-heated diamond anvil cell,

111 and analysis must be performed with $\sim 100-\mathrm{nm}$-scale spatial resolution of typical grain sizes of

112 run products. Dolomite, a major constituent of subducted marble, provides a unique advantage as

113 a starting material as it has a mixed $\mathrm{Mg}-\mathrm{Fe}-\mathrm{Ca}$ carbonate composition homogeneous to $<\mathrm{nm}$

114 scale. Natural dolomite crystals with composition determined to be $\left(\mathrm{Mg}_{0.38} \mathrm{Ca}_{0.59} \mathrm{Fe}_{0.03}\right) \mathrm{CO}_{3}$ by $\mathrm{X}-$

115 ray fluorescence spectroscopy and structure confirmed by X-ray diffraction were used as starting

116 materials. Single dolomite crystals were polished to $\sim 10$-micron thickness and dried in a $120^{\circ} \mathrm{C}$

117 oven overnight before loading. 3-micron thick $99.85 \%$ iron foil was machined into discs with a

118 ps-pulsed 532-nm laser or cut with a razor blade. Iron foils were loaded sandwiched between

119 dolomite crystals in symmetric diamond anvil cells. No other pressure standard or medium was

120 loaded in order to prevent reactions with other components and contamination of the chemical

121 system. Sample sandwiches were loaded within chambers cut in Re gaskets in diamond anvil

122 cells. Diamond anvils with flat culets of 200 micron diameter or beveled culets of 150 micron

123 diameter were chosen to generate pressures corresponding to the lower mantle.

124 Samples were compressed to pressures of $51,66,77$, and $113 \mathrm{GPa}$, as determined by the

125 equation of state of the iron foil (Mao et al., 1990) before laser heating (Table 1). Pressures were

126 not measured during heating due to chemical reaction of the iron foil with the dolomite, but were

127 likely $~ 7-10 \mathrm{GPa}$ higher than those reported here due to thermal pressure. Laser heating was

128 performed with in situ X-ray diffraction at the GSECARS sector of the Advanced Photon Source 
129 (Prakapenka et al., 2008). The laser spot was focused to a diameter of $\sim 10$ microns with a flat130 top beam shape. Each sample was heated for 10-20 min at 1800-2500 K.

131 After recovery to ambient conditions, each heated spot was sectioned using a Zeiss NVision

13240 dual-beam scanning electron microscope and focused $\mathrm{Ga}^{+}$ion beam (Centre Interdisciplinaire

133 Microscopie de Electronique (CIME), EPFL). Each sample was coated with $15 \mathrm{~nm}$ Au to reduce

134 charging in the scanning electron microscope. To protect the samples from damage by the $\mathrm{Ga}^{+}$

135 ion beam, an additional 1-2 micron thick layer of Pt or $\mathrm{C}$ was deposited across the centers of

136 heated spots. Thin sections of each heated spot were extracted and polished to electron

137 transparency $(\sim 100 \mathrm{~nm}$ thickness).

138 Imaging of recovered thin sections was performed with scanning transmission election

139 microscopy (S/TEM) and energy-dispersive X-ray spectroscopy (EDX) in a FEI Tecnai Osiris

140 analytical TEM (CIME, EPFL). Accelerating voltage for these measurements was $200 \mathrm{kV}$. The

141 Osiris TEM is equipped with four wide-solid-angle detectors for high-speed chemical

142 measurements by EDX spectroscopy. EDX maps were scanned over 1024x1024 pixel areas with

143 pixel dwell time of 50 microseconds. Typical count rates were $\sim 40,000-50,000$ counts per

144 second. Chemical mapping prevents migration of elements due to damage by the electron beam.

145 Uncertainties in compositions were determined from standard deviations of EDX measurements

146 obtained from selected regions within multiple grains.

\section{$147 \quad$ 3. Results}

148 Laser-heating dolomite-iron sandwiches from both sides produces a lens-shaped heated

149 zone (Figure 1), as predicted by models (Kiefer and Duffy, 2005; Rainey et al., 2013) and

150 measurements (Campbell, 2008) of thermal diffusion in the diamond anvil cell. Laser absorption 
151 and diffraction indicate that the sample reaches a steady state within a few minutes. The hottest

152 region of the sample is the laser-absorbing central iron layer. The insulating dolomite layers

153 experience both axial and radial temperature gradients, with highest temperatures at the contacts

154 with the iron foil and lowest temperatures at the diamond anvil surface. High-resolution TEM

155 inspection of recovered thin sections indicates that grain sizes decrease away from the surface of

156 the iron foil, consistent with this thermal gradient (Figure 1). At the cool upper and lower edges

157 of the heated spot, ribbons of magnesium and calcium carbonate exsolve from the dolomite

158 (Figure 2), as has been observed at lower pressures (Sato and Katsura, 2001; Shirasaka et al.,

159 2002).

160 Both EDX analysis of recovered thin sections in the TEM (Figure 3) and diffraction

161 patterns obtained during and after sub-solidus laser heating (Figure 4b) show that the metallic

162 iron at the sample center reacts completely with the dolomite to generate a mixture of $\mathrm{FeO}$ and

$163 \mathrm{Fe}_{7} \mathrm{C}_{3}$. The iron layer thus exhibits oxidation which must be compensated by reduction of the

164 carbonate. Within the carbonate layer near the hot interface with the iron foil, three phases are

165 found in all samples: diamond, Mg-bearing ferropericlase, and $\mathrm{CaCO}_{3}$ (Figure 3). The diffusion

166 of iron from the sample center propagates breakdown of the magnesium carbonate to diamond

167 and ferropericlase. Due to diffusion, this ferropericlase has much more $\mathrm{MgO}$ than the $\mathrm{FeO}$ at the

168 sample center (Figures 5-6). Unlike $\mathrm{MgCO}_{3}, \mathrm{CaCO}_{3}$ exsolves from the dolomite but is never

169 observed to break down. EDX composition analysis confirms that the $\mathrm{CaCO}_{3}$ phase retains both

$170 \mathrm{O}$ and $\mathrm{C}$ within measurement error and there is no evidence for measurable $\mathrm{Ca}$ in any other phase

171 (Figure 5). At the pressures examined here, the stable polymorph of $\mathrm{CaCO}_{3}$ is the post-aragonite

172 phase (Ono et al., 2005). Post-aragonite-type $\mathrm{CaCO}_{3}$ is observed in diffraction patterns after

173 heating (Figure 4b), along with unreacted dolomite. These experiments show that a carbonate- 
174 rich rock such as subducted marble subjected to reducing conditions in contact with metallic

175 iron, post-aragonite-type $\mathrm{CaCO}_{3}$ is a more stable form of carbonate than $\mathrm{MgCO}_{3}$ throughout the

176 lower mantle pressure range.

\section{Discussion}

The mixture of $(\mathrm{Mg}, \mathrm{Fe}) \mathrm{O}$, diamond, $\mathrm{Fe}_{7} \mathrm{C}_{3}$ and $\mathrm{CaCO}_{3}$ is produced by redox coupling

179 between the iron and carbon and breakdown of the $\mathrm{MgCO}_{3}$ component. The following reactions

180 explain these observations:

$$
\mathrm{MgCO}_{3}+2 \mathrm{Fe} \rightarrow \mathrm{C}+\mathrm{MgO}+2 \mathrm{FeO}
$$$$
3 \mathrm{MgCO}_{3}+13 \mathrm{Fe} \rightarrow \mathrm{Fe}_{7} \mathrm{C}_{3}+3 \mathrm{MgO}+6 \mathrm{FeO}
$$

In the center of the sample, the system is saturated in iron, leading to a mixture

184 dominated by $\mathrm{Fe}_{7} \mathrm{C}_{3}$ and $\mathrm{FeO}$. In the region where the carbonate breaks down, the carbon/iron 185 ratio is higher, and reduced carbon is found in diamonds rather than carbides. The breakdown of $186 \mathrm{MgCO}_{3}$ is favorable in all heated regions in the presence of iron. The stable host phase for 187 carbon is controlled by the $\mathrm{Fe} / \mathrm{MgCO}_{3}$ ratio of reactants. Recent studies have largely focused on $188(\mathrm{Mg}, \mathrm{Fe}) \mathrm{CO}_{3}$ as a host phase for oxidized carbon in the deep Earth, as the melting point of 189 magnesite or ferromagnesite is higher than that of $\mathrm{CaCO}_{3}$ in the transition zone. However, $190(\mathrm{Mg}, \mathrm{Fe}) \mathrm{CO}_{3}$ is much more susceptible to redox breakdown than $\mathrm{CaCO}_{3}$.

191 Redox breakdown will promote diamond formation from $(\mathrm{Mg}, \mathrm{Fe}) \mathrm{CO}_{3}$ in carbonated 192 eclogite and peridotite. This study and others have shown that diamonds nucleate and grow 193 directly from carbonates at subsolidus, reducing conditions, and inclusion-bearing diamonds 194 used as evidence that carbonates are stable to great depths in the mantle record incomplete redox 195 breakdown (e.g. Wang et al., 1996). Reducing agents relevant to carbonate stability at different 
196 stages of Earth's chemical evolution include graphite (Pal'yanov et al., 1999), $\mathrm{H}_{2}$ (Pal'yanov et 197 al., 2002), Si metal (Siebert et al., 2005), and Fe metal. In a mixture of carbonate and Fe-Si alloy, $198 \mathrm{Si}$ and $\mathrm{C}$ were oxidized, producing a mixture in which diamonds coexist with metallic iron 199 (Siebert et al., 2005). Other studies have suggested either that pure iron and pure carbon should 200 not coexist in equilibrium (Rouquette et al., 2008; Scott et al., 2001) or that iron carbides and 201 diamond compete as hosts of reduced carbon (Iizuka et al., 1996). In this study, metallic iron 202 reacts completely to carbide and oxide, indicating that the system is oversaturated in carbon.

203 Because the mantle has been suggested to be a highly reducing environment, saturated in 204 metallic iron (Frost et al., 2004; Frost and McCammon, 2008; Rohrbach et al., 2007; Rohrbach 205 and Schmidt, 2011), carbonate in this system will be susceptible to redox breakdown at 206 subsolidus temperatures. Reduction of subducted carbonates by interaction with metallic iron 207 was previously explored at relatively modest depths (Martin and Hammouda, 2011; Martirosyan 208 et al., 2015a, 2015b; Stagno et al., 2011). Most previous studies were conducted at pressures 209 reaching $\sim 6 \mathrm{GPa}$ (Martin and Hammouda, 2011; Martirosyan et al., 2015a, 2015b), too low to 210 model the depths at which metallic iron becomes available to react with subducted carbonate.

211 Metallic iron may also be present in the lower mantle due to charge disproportionation in 212 silicates (Frost et al., 2004; Rohrbach et al., 2007), mixing at the CMB (Knittle and Jeanloz, 213 1989; Otsuka and Karato, 2012), or residue of magma ocean solidification (Zhang et al., 2016).

214 Recently, iron-magnesite mixtures were examined at $16-45 \mathrm{GPa}$ and $1500-1700{ }^{\circ} \mathrm{C}$,

215 corresponding to transition zone to lower mantle depths (Stagno et al., 2011). At these

216 conditions, diamonds are observed to coexist with magnesite, ferropericlase and carbon-free

217 iron-iridium alloy. The Ir alloy was used to determine that $f_{02}$ was $\sim 3 \log$ units above the iron218 wüstite buffer. The breakdown of magnesite observed here may imply lower $f_{\mathrm{O} 2}$ conditions, 
219 perhaps due to the sample environment in the diamond anvil cell or higher pressures. For

220 subducted marble or carbonated silicate lithologies that reach a reduced zone near the core-

221 mantle boundary, $(\mathrm{Mg}, \mathrm{Fe}) \mathrm{CO}_{3}$ cannot be preserved.

222 Spin transitions in ferromagnesite have recently been studied for their potential to affect

223 carbonate stability (Lin et al., 2012; Liu et al., 2015). The spin transition results in a $\sim 8 \%$ unit

224 cell volume collapse for $\left(\mathrm{Mg}_{0.35} \mathrm{Fe}_{0.65}\right) \mathrm{CO}_{3}$ ( Lin et al., 2012) and would thus be expected to have

225 a significant effect on phase equilibria. As the minimum pressure examined in these experiments

226 is above the spin transition pressure, we are unable to evaluate whether the spin transition is

227 related to the observed breakdown of $(\mathrm{Mg}, \mathrm{Fe}) \mathrm{CO}_{3}$. The susceptibility of $(\mathrm{Mg}, \mathrm{Fe}) \mathrm{CO}_{3}$ to

228 disproportionation at low $f_{\mathrm{O} 2}$ suggests that low-spin iron-bearing carbonates are unlikely to be

229 stable in Earth's mantle.

$230 \mathrm{CaCO}_{3}$ is less sensitive than $(\mathrm{Mg}, \mathrm{Fe}) \mathrm{CO}_{3}$ to redox breakdown, but melting, reaction with

231 silicates, and buoyancy remain challenging barriers to its transport to the deep mantle. Although

232 the melting point of $\mathrm{CaCO}_{3}$ (Bayarjargal et al., 2010; Thomson et al., 2014) is well above a 1600

233 K adiabatic geotherm (Brown and Shankland, 1981), the eutectic melting point for carbonate

234 mixtures is substantially lower and comparable to the geotherm (Thomson et al., 2014). Eutectic

235 melting has been argued to effectively block carbonate transport to the lower mantle (Thomson

236 et al., 2016). However, no evidence is observed for melting of the dolomite carbonate in this

237 work. Moreover, geotherms both for the average mantle (e.g. Brown and Shankland, 1981;

238 Andrault et al., 2011; Nomura et al., 2014) and subducting slabs (e.g. Andrault et al., 2014)

239 remain highly uncertain. The key question is whether, for realistic subducted carbonates, the

240 melting point of the mixture is high enough relative to the temperature in the slab to prevent

241 diamond formation. With temperature uncertainties of at least 100s K, in addition to potential 
242 kinetic effects on the efficiency of carbonate reduction and melting (Martirosyan et al., 2016),

243 preservation of carbonates in the lower mantle cannot yet be ruled out. $\mathrm{CaCO}_{3}$ is also expected to

244 be destabilized in the mantle by reaction with $(\mathrm{Mg}, \mathrm{Fe}) \mathrm{SiO}_{3}$ in peridotite or eclogite to produce

$245 \mathrm{CaSiO}_{3}$ and $(\mathrm{Mg}, \mathrm{Fe}) \mathrm{CO}_{3}$ (Biellmann et al., 1993; Seto et al., 2008). This reaction suggests

$246 \mathrm{CaCO}_{3}$ is most likely to be preserved in silicate-poor, dolomite-rich marble entrained with

247 subducting slabs. Because metasediment is likely to be as much as $\sim 5-15 \%$ less dense than

248 surrounding peridotite, $\sim 100 \mathrm{~m}$ packages of marble would likely rise to the surface through

249 diapirism (Kelemen and Manning, 2015). Transport of $\mathrm{CaCO}_{3}$ to the deep mantle would require

250 carbonate to reside in layers or regions thin enough to be entrained with the cold slab, but thick

251 enough that slow diffusion blocks reaction of carbonate with silicates.

252 Observations in this and other experimental studies challenge interpretation of oxide

253 inclusions in identified in diamonds. While traditionally $(\mathrm{Mg}, \mathrm{Fe}) \mathrm{O}$ inclusions have been

254 considered to be a smoking gun for formation in the Earth's lower mantle, as a leftover from the

255 breakdown of $\mathrm{Mg}_{2} \mathrm{SiO}_{4}$ to lower mantle bridgmanite (Kaminsky, 2012), carbonate

256 disproportionation is another possible mechanism for oxide formation (Tappert et al., 2005;

257 Thomson et al., 2016). Direct observation of lower mantle silicates of appropriate compositions

258 is necessary to confirm ultra-deep diamond origin.

259 5. Conclusions

260 Magnesite-siderite is not a likely host phase for carbonate in reduced regions of the deep

261 lower mantle, but post-aragonite-type $\mathrm{CaCO}_{3}$ may be stable in carbonate-rich lithologies. While

$262 \mathrm{CaCO}_{3}$ undergoes more pressure-induced polymorphic transitions than $(\mathrm{Mg}, \mathrm{Fe}) \mathrm{CO}_{3}$ in the deep

263 mantle and may be more likely to react with lower mantle silicates, relative to $(\mathrm{Mg}, \mathrm{Fe}) \mathrm{CO}_{3}$ it is

264 less likely to participate in redox reactions. A low $f_{02}$ environment in the lower mantle (Frost and 
McCammon, 2008; Rohrbach and Schmidt, 2011) will promote breakdown of ferromagnesite but

$266 \mathrm{CaCO}_{3}$ will remain stable to pressure, temperature and redox conditions near the base of the

267 lower mantle if isolated from silicates. A carbonate-rich heterogeneity near the base of the

268 mantle could be a high-pressure marble, with $\mathrm{CaCO}_{3}$ associated with diamonds formed by

269 breakdown of $\mathrm{MgCO}_{3}$.

270 Diamond-bearing marble in the lower mantle is not likely to be directly observable by

271 seismic tomography, but could impact observations of heterogeneous redox conditions at depth

272 due to mantle convection and subduction and/or signatures of Earth's chemical evolution.

273 Heterogeneous oxygen fugacity at depth is evident in diamond inclusions (Brenker et al., 2007;

274 Walter et al., 2011; Ryabchikov and Kaminsky, 2013; Smith et al., 2016; Kaminsky, 2012) as

275 well as chemical variation in both mid-ocean ridge basalts due to relative contributions of

276 depleted and primitive mantle sources (Cottrell and Kelley, 2013) and ocean island basalts

277 potentially sourced from the core-mantle boundary (White, 2010). The interpretation of available

278 redox proxies for the deep mantle over deep time, particularly presence of carbonate (e.g.

279 Brenker et al., 2007) and speciation of iron (Frost and McCammon, 2008), must be evaluated in

280 the light of the multivariable dependence of stability of $\mathrm{MgCO}_{3}$ and $\mathrm{CaCO}_{3}$ on temperature, bulk

281 composition of the phase assemblage and $f_{02}$.

\section{Acknowledgments:}

283 The authors acknowledge M. Hirschmann for thoughtful comments that improved this

284 manuscript. We thank A. Magrez for assistance with X-ray diffraction and X-ray fluorescence

285 characterization of the starting material. F. Bobard, D. Alexander and E. Oveisi provided training

286 and advice for focused ion beam and transmission electron microscopy. S. M. Dorfman

287 acknowledges the Marie Heim-Vögtlin program of the Swiss National Science Foundation for

288 financial support through project PMPDP2 151256. J. Badro acknowledges the financial support

289 of the Sloan Foundation's Deep Carbon Observatory and UnivEarthS Labex program at

290 Sorbonne Paris Cité (ANR-10-LABX-0023 and ANR-11-IDEX-0005-02). GeoSoilEnviroCARS 
291 is supported by the National Science Foundation - Earth Sciences (EAR-0622171), Department 292 of Energy - Geosciences (DE-FG02-94ER14466) and the State of Illinois.

293 Data reported in this paper are available by request from S. M. Dorfman at 294 dorfman3@msu.edu.

295

296 
Andrault, D., Bolfan-Casanova, N., Nigro, G.L., Bouhifd, M.A., Garbarino, G., Mezouar, M., 2011. Solidus and liquidus profiles of chondritic mantle: Implication for melting of the Earth across its history. Earth Planet. Sci. Lett. 304, 251-259. https://doi.org/10.1016/j.eps1.2011.02.006

Andrault, D., Pesce, G., Bouhifd, M.A., Bolfan-Casanova, N., Hénot, J.-M., Mezouar, M., 2014. Melting of subducted basalt at the core-mantle boundary. Science 344, 892-895. https://doi.org/10.1126/science.1250466

Arima, M., Kozai, Y., Akaishi, M., 2002. Diamond nucleation and growth by reduction of carbonate melts under high-pressure and high-temperature conditions. Geology 30, 691694. https://doi.org/10.1130/0091-7613(2002)030<0691:DNAGBR >2.0.CO;2

Bayarjargal, L., Shumilova, T.G., Friedrich, A., Winkler, B., 2010. Diamond formation from $\mathrm{CaCO}_{3}$ at high pressure and temperature. Eur. J. Mineral. 22, 29-34. https://doi.org/10.1127/0935-1221/2010/0021-1986

Biellmann, C., Gillet, P., Guyot, F., Peyronneau, J., Reynard, B., 1993. Experimental evidence for carbonate stability in the Earth's lower mantle. Earth Planet. Sci. Lett. 118, 31-41. https://doi.org/10.1016/0012-821X(93)90157-5

Boulard, E., Gloter, A., Corgne, A., Antonangeli, D., Auzende, A.-L., Perrillat, J.-P., Guyot, F., Fiquet, G., 2011. New host for carbon in the deep Earth. PNAS 108, 5184-5187. https://doi.org/10.1073/pnas.1016934108

Boulard, E., Menguy, N., Auzende, A.L., Benzerara, K., Bureau, H., Antonangeli, D., Corgne, A., Morard, G., Siebert, J., Perrillat, J.P., Guyot, F., Fiquet, G., 2012. Experimental investigation of the stability of Fe-rich carbonates in the lower mantle. J. Geophys. Res. 117, B02208. https://doi.org/10.1029/2011JB008733

Brenker, F.E., Vollmer, C., Vincze, L., Vekemans, B., Szymanski, A., Janssens, K., Szaloki, I., Nasdala, L., Joswig, W., Kaminsky, F., 2007. Carbonates from the lower part of transition zone or even the lower mantle. Earth Planet. Sci. Lett. 260, 1-9. https://doi.org/10.1016/j.eps1.2007.02.038

Brown, J.M., Shankland, T.J., 1981. Thermodynamic parameters in the Earth as determined from seismic profiles. Geophys. J. Int. 66, 579-596. https://doi.org/10.1111/j.1365246X.1981.tb04891.x

Campbell, A.J., 2008. Measurement of temperature distributions across laser heated samples by multispectral imaging radiometry. Rev. Sci. Instrum. 79, 015108. https://doi.org/10.1063/1.2827513

Cottrell, E., Kelley, K.A., 2013. Redox Heterogeneity in Mid-Ocean Ridge Basalts as a Function of Mantle Source. Science 340, 1314-1317. https://doi.org/10.1126/science.1233299

Dasgupta, R., Hirschmann, M.M., 2010. The deep carbon cycle and melting in Earth's interior. Earth Planet. Sci. Lett. 298, 1-13. https://doi.org/10.1016/j.epsl.2010.06.039

Fei, Y., Zhang, L., Corgne, A., Watson, H., Ricolleau, A., Meng, Y., Prakapenka, V., 2007. Spin transition and equations of state of $(\mathrm{Mg}, \mathrm{Fe}) \mathrm{O}$ solid solutions. Geophys. Res. Lett. 34, L17307.

Fischer, R.A., Campbell, A.J., Shofner, G.A., Lord, O.T., Dera, P., Prakapenka, V.B., 2011. Equation of state and phase diagram of FeO. Earth Planet. Sci. Lett. 304, 496-502. https://doi.org/10.1016/j.epsl.2011.02.025 
Frost, D.J., Liebske, C., Langenhorst, F., McCammon, C.A., Trønnes, R.G., Rubie, D.C., 2004. Experimental evidence for the existence of iron-rich metal in the Earth's lower mantle. Nature 428, 409-412. https://doi.org/10.1038/nature02413

Frost, D.J., McCammon, C.A., 2008. The redox state of Earth's mantle. Annu. Rev. Earth Planet. Sci. 36, 389-420. https://doi.org/10.1146/annurev.earth.36.031207.124322

Ghosh, S., Litasov, K., Ohtani, E., 2014. Phase relations and melting of carbonated peridotite between 10 and $20 \mathrm{GPa}$ a proxy for alkali- and $\mathrm{CO} 2$-rich silicate melts in the deep mantle. Contrib Mineral Petrol 167, 964. https://doi.org/10.1007/s00410-014-0964-z

Harte, B., 2010. Diamond formation in the deep mantle: the record of mineral inclusions and their distribution in relation to mantle dehydration zones. Mineral. Mag. 74, 189-215. https://doi.org/10.1180/minmag.2010.074.2.189

Iizuka, M., Ikawa, H., Fukunaga, O., 1996. Nucleation and growth of diamond using Ni-Ti, Ni$\mathrm{Nb}$ and Fe-B alloy as solvents. Diamond and Related Materials 5, 38-42. https://doi.org/10.1016/0925-9635(95)00329-0

Isshiki, M., Irifune, T., Hirose, K., Ono, S., Ohishi, Y., Watanuki, T., Nishibori, E., Takata, M., Sakata, M., 2004. Stability of magnesite and its high-pressure form in the lowermost mantle. Nature 427, 60-63. https://doi.org/10.1038/nature02181

Kaminsky, F., 2012. Mineralogy of the lower mantle: A review of "super-deep" mineral inclusions in diamond. Earth-Sci. Rev. 110, 127-147. https://doi.org/10.1016/j.earscirev.2011.10.005

Kaminsky, F.V., Ryabchikov, I.D., Wirth, R., 2016. A primary natrocarbonatitic association in the Deep Earth. Miner Petrol 110, 387-398. https://doi.org/10.1007/s00710-015-0368-4

Katsura, T., Ito, E., 1990. Melting and subsolidus phase relations in the $\mathrm{MgSiO}_{3}-\mathrm{MgCO}_{3}$ system at high pressures: implications to evolution of the Earth's atmosphere. Earth Planet. Sci. Lett. 99, 110-117. https://doi.org/10.1016/0012-821X(90)90074-8

Kelemen, P.B., Manning, C.E., 2015. Reevaluating carbon fluxes in subduction zones, what goes down, mostly comes up. PNAS 112, E3997-E4006. https://doi.org/10.1073/pnas.1507889112

Kiefer, B., Duffy, T.S., 2005. Finite element simulations of the laser-heated diamond-anvil cell. J. Appl. Phys. 97, 114902. https://doi.org/10.1063/1.1906292

Knittle, E., Jeanloz, R., 1989. Simulating the core-mantle boundary: An experimental study of high-pressure reactions between silicates and liquid iron. Geophys. Res. Lett. 16, 609612. https://doi.org/198910.1029/GL016i007p00609

Lin, J.-F., Liu, J., Jacobs, C., Prakapenka, V.B., 2012. Vibrational and elastic properties of ferromagnesite across the electronic spin-pairing transition of iron. Am. Mineral. 97, 583-591. https://doi.org/10.2138/am.2012.3961

Liu, J., Lin, J.-F., Prakapenka, V.B., 2015. High-Pressure Orthorhombic Ferromagnesite as a Potential Deep-Mantle Carbon Carrier. Sci. Rep. 5. https://doi.org/10.1038/srep07640

Mao, H.K., Wu, Y., Chen, L.C., Shu, J.F., Jephcoat, A.P., 1990. Static Compression of Iron to $300 \mathrm{GPa}$ and Fe0.8Ni0.2 Alloy to $260 \mathrm{GPa}$ : Implications for Composition of the Core. J. Geophys. Res. 95, 21737-21742. https://doi.org/199010.1029/JB095iB13p21737

Martin, A.M., Hammouda, T., 2011. Role of iron and reducing conditions on the stability of dolomite + coesite between 4.25 and $6 \mathrm{GPa}-$ a potential mechanism for diamond formation during subduction. Eur J Mineral 23, 5-16. https://doi.org/10.1127/0935$1221 / 2010 / 0022-2067$ 
Martinez, I., Chamorro Peréz, E.M., Matas, J., Gillet, P., Vidal, G., 1998. Experimental investigation of silicate-carbonate system at high pressure and high temperature. J. Geophys. Res. 103, 5143-5163. https://doi.org/10.1029/97JB03401

Martirosyan, N.S., Litasov, K.D., Shatskiy, A., Ohtani, E., 2015a. The reactions between iron and magnesite at $6 \mathrm{GPa}$ and $1273-1873 \mathrm{~K}$ : Implication to reduction of subducted carbonate in the deep mantle. J. Miner. Petrol. Sci. 110, 49-59. https://doi.org/10.2465/jmps.141003a

Martirosyan, N.S., Litasov, K.D., Shatskiy, A.F., Ohtani, E., 2015b. Reactions of iron with calcium carbonate at $6 \mathrm{GPa}$ and $1273-1873 \mathrm{~K}$ : implications for carbonate reduction in the deep mantle. Russ. Geol. Geophys. 56, 1322-1331. https://doi.org/10.1016/j.rgg.2015.08.008

Martirosyan, N.S., Yoshino, T., Shatskiy, A., Chanyshev, A.D., Litasov, K.D., 2016. The $\mathrm{CaCO}_{3}-\mathrm{Fe}$ interaction: Kinetic approach for carbonate subduction to the deep Earth's mantle. Physics of the Earth and Planetary Interiors 259, 1-9. https://doi.org/10.1016/j.pepi.2016.08.008

Meyer, H.O.A., McCallum, M.E., 1986. Mineral Inclusions in Diamonds from the Sloan Kimberlites, Colorado. J. Geol. 94, 600-612. https://doi.org/10.1086/629062

Nomura, R., Hirose, K., Uesugi, K., Ohishi, Y., Tsuchiyama, A., Miyake, A., Ueno, Y., 2014. Low Core-Mantle Boundary Temperature Inferred from the Solidus of Pyrolite. Science 343, 522-525. https://doi.org/10.1126/science. 1248186

Oganov, A.R., Ono, S., Ma, Y., Glass, C.W., Garcia, A., 2008. Novel high-pressure structures of $\mathrm{MgCO}_{3}, \mathrm{CaCO}_{3}$ and $\mathrm{CO}_{2}$ and their role in Earth's lower mantle. Earth Planet. Sci. Lett. 273, 38-47. https://doi.org/10.1016/j.eps1.2008.06.005

Ono, S., Kikegawa, T., Ohishi, Y., 2007. High-pressure transition of $\mathrm{CaCO}_{3}$. Am. Mineral. 92, 1246-1249. https://doi.org/10.2138/am.2007.2649

Ono, S., Kikegawa, T., Ohishi, Y., Tsuchiya, J., 2005. Post-aragonite phase transformation in $\mathrm{CaCO}_{3}$ at $40 \mathrm{GPa}$. Am. Mineral. 90, 667-671. https://doi.org/10.2138/am.2005.1610

Otsuka, K., Karato, S., 2012. Deep penetration of molten iron into the mantle caused by a morphological instability. Nature 492, 243-246. https://doi.org/10.1038/nature11663

Pal'yanov, Y.N., Bataleva, Y.V., Sokol, A.G., Borzdov, Y.M., Kupriyanov, I.N., Reutsky, V.N., Sobolev, N.V., 2013. Mantle-slab interaction and redox mechanism of diamond formation. PNAS 201313340. https://doi.org/10.1073/pnas.1313340110

Pal'yanov, Y.N., Sokol, A.G., Borzdov, Y.M., Khokhryakov, A.F., Sobolev, N.V., 2002. Diamond formation through carbonate-silicate interaction. Am. Mineral. 87, 1009-1013.

Pal'yanov, Y.N., Sokol, A.G., Borzdov, Y.M., Khokhryakov, A.F., Sobolev, N.V., 1999. Diamond formation from mantle carbonate fluids. Nature 400, 417-418. https://doi.org/10.1038/22678

Phillips, D., Harris, J.W., 1995. Geothermobarometry of diamond inclusions from the De Beers Pool Mines, Kimberley, South Africa. Sixth International Kimberlite Conference, Novosibirsk, Extended Abstracts 441-443.

Pickard, C.J., Needs, R.J., 2015. Structures and stability of calcium and magnesium carbonates at mantle pressures. Phys. Rev. B 91, 104101. https://doi.org/10.1103/PhysRevB.91.104101

Prakapenka, V.B., Kubo, A., Kuznetsov, A., Laskin, A., Shkurikhin, O., Dera, P., Rivers, M.L., Sutton, S.R., 2008. Advanced flat top laser heating system for high pressure research at 
GSECARS: application to the melting behavior of germanium. High Pressure Res. 28, 225-235. https://doi.org/10.1080/08957950802050718

Rainey, E.S.G., Hernlund, J.W., Kavner, A., 2013. Temperature distributions in the laser-heated diamond anvil cell from 3-D numerical modeling. J. Appl. Phys. 114, 4905. https://doi.org/10.1063/1.4830274

Rohrbach, A., Ballhaus, C., Golla-Schindler, U., Ulmer, P., Kamenetsky, V.S., Kuzmin, D.V., 2007. Metal saturation in the upper mantle. Nature 449, 456-458. https://doi.org/10.1038/nature06183

Rohrbach, A., Schmidt, M.W., 2011. Redox freezing and melting in the Earth's deep mantle resulting from carbon-iron redox coupling. Nature 472, 209-212. https://doi.org/10.1038/nature09899

Rouquette, J., Dolejš, D., Kantor, I.Y., McCammon, C.A., Frost, D.J., Prakapenka, V.B., Dubrovinsky, L.S., 2008. Iron-carbon interactions at high temperatures and pressures. Appl. Phys. Lett. 92, 121912. https://doi.org/10.1063/1.2892400

Ryabchikov, I.D., Kaminsky, F.V., 2013. Oxygen potential of diamond formation in the lower mantle. Geol. Ore Deposits 55, 1-12. https://doi.org/10.1134/S1075701513010066

Sato, K., Katsura, T., 2001. Experimental investigation on dolomite dissociation into aragonite+magnesite up to $8.5 \mathrm{GPa}$. Earth Planet. Sci. Lett. 184, 529-534. https://doi.org/10.1016/S0012-821X(00)00346-0

Scott, H.P., Williams, Q., Knittle, E., 2001. Stability and equation of state of $\mathrm{Fe}_{3} \mathrm{C}$ to $73 \mathrm{GPa}$ : Implications for carbon in the Earth's core. Geophys. Res. Lett. 28, 1875-1878. https://doi.org/10.1029/2000GL012606

Seto, Y., Hamane, D., Nagai, T., Fujino, K., 2008. Fate of carbonates within oceanic plates subducted to the lower mantle, and a possible mechanism of diamond formation. Phys Chem Minerals 35, 223-229. https://doi.org/10.1007/s00269-008-0215-9

Shirasaka, M., Takahashi, E., Nishihara, Y., Matsukage, K., Kikegawa, T., 2002. In situ X-ray observation of the reaction dolomite $=$ aragonite + magnesite at 900-1300 K. Am. Mineral. 87, 922-930.

Siebert, J., Guyot, F., Malavergne, V., 2005. Diamond formation in metal-carbonate interactions. Earth Planet. Sci. Lett. 229, 205-216. https://doi.org/10.1016/j.epsl.2004.10.036

Smith, E.M., Shirey, S.B., Nestola, F., Bullock, E.S., Wang, J., Richardson, S.H., Wang, W., 2016. Large gem diamonds from metallic liquid in Earth's deep mantle. Science 354, 1403-1405. https://doi.org/10.1126/science.aal1303

Solopova, N.A., Dubrovinsky, L., Spivak, A.V., Litvin, Y.A., Dubrovinskaia, N., 2014. Melting and decomposition of $\mathrm{MgCO}_{3}$ at pressures up to $84 \mathrm{GPa}$. Phys Chem Minerals 42, 73-81. https://doi.org/10.1007/s00269-014-0701-1

Speziale, S., Zha, C.S., Duffy, T.S., Hemley, R.J., Mao, H., 2001. Quasi-hydrostatic compression of magnesium oxide to $52 \mathrm{GPa}$ - Implications for the pressure-volume-temperature equation of state. J. Geophys. Res. 106, 515-528. https://doi.org/10.1029/2000JB900318

Spivak, A.V., Dubrovinskii, L.S., Litvin, Y.A., 2011. Congruent melting of calcium carbonate in a static experiment at $3500 \mathrm{~K}$ and 10-22 GPa: Its role in the genesis of ultradeep diamonds. Dokl. Earth Sc. 439, 1171-1174. https://doi.org/10.1134/S1028334X11080319 
Stagno, V., Frost, D.J., McCammon, C.A., Mohseni, H., Fei, Y., 2015. The oxygen fugacity at which graphite or diamond forms from carbonate-bearing melts in eclogitic rocks. Contrib Mineral Petrol 169, 16. https://doi.org/10.1007/s00410-015-1111-1

Stagno, V., Ojwang, D.O., McCammon, C.A., Frost, D.J., 2013. The oxidation state of the mantle and the extraction of carbon from Earth's interior. Nature 493, 84-88. https://doi.org/10.1038/nature1 1679

Stagno, V., Tange, Y., Miyajima, N., McCammon, C.A., Irifune, T., Frost, D.J., 2011. The stability of magnesite in the transition zone and the lower mantle as function of oxygen fugacity. Geophys. Res. Lett. 38, L19309. https://doi.org/10.1029/2011GL049560

Tao, R., Fei, Y., Zhang, L., 2013. Experimental determination of siderite stability at high pressure. Am. Mineral. 98, 1565-1572. https://doi.org/10.2138/am.2013.4351

Tappert, R., Stachel, T., Harris, J.W., Muehlenbachs, K., Ludwig, T., Brey, G.P., 2005. Subducting oceanic crust: The source of deep diamonds. Geology 33, 565-568. https://doi.org/10.1130/G21637.1

Thomson, A.R., Walter, M.J., Kohn, S.C., Brooker, R.A., 2016. Slab melting as a barrier to deep carbon subduction. Nature 529, 76-79. https://doi.org/10.1038/nature16174

Thomson, A.R., Walter, M.J., Lord, O.T., Kohn, S.C., 2014. Experimental determination of melting in the systems enstatite-magnesite and magnesite-calcite from 15 to $80 \mathrm{GPa}$. Am. Mineral. 99, 1544-1554. https://doi.org/10.2138/am.2014.4735

Walter, M.J., Kohn, S.C., Araujo, D., Bulanova, G.P., Smith, C.B., Gaillou, E., Wang, J., Steele, A., Shirey, S.B., 2011. Deep Mantle Cycling of Oceanic Crust: Evidence from Diamonds and Their Mineral Inclusions. Science 334, 54-57. https://doi.org/10.1126/science.1209300

Wang, A., Pasteris, J.D., Meyer, H.O.A., Dele-Duboi, M.L., 1996. Magnesite-bearing inclusion assemblage in natural diamond. Earth Planet. Sci. Lett. 141, 293-306. https://doi.org/10.1016/0012-821X(96)00053-2

White, W.M., 2010. Oceanic Island Basalts and Mantle Plumes: The Geochemical Perspective. Annual Review of Earth and Planetary Sciences 38, 133-160. https://doi.org/10.1146/annurev-earth-040809-152450

Zhang, Z., Dorfman, S.M., Labidi, J., Zhang, S., Li, M., Manga, M., Stixrude, L., McDonough, W.F., Williams, Q., 2016. Primordial metallic melt in the deep mantle. Geophys. Res. Lett. 43, 3693-3699. https://doi.org/10.1002/2016GL068560 


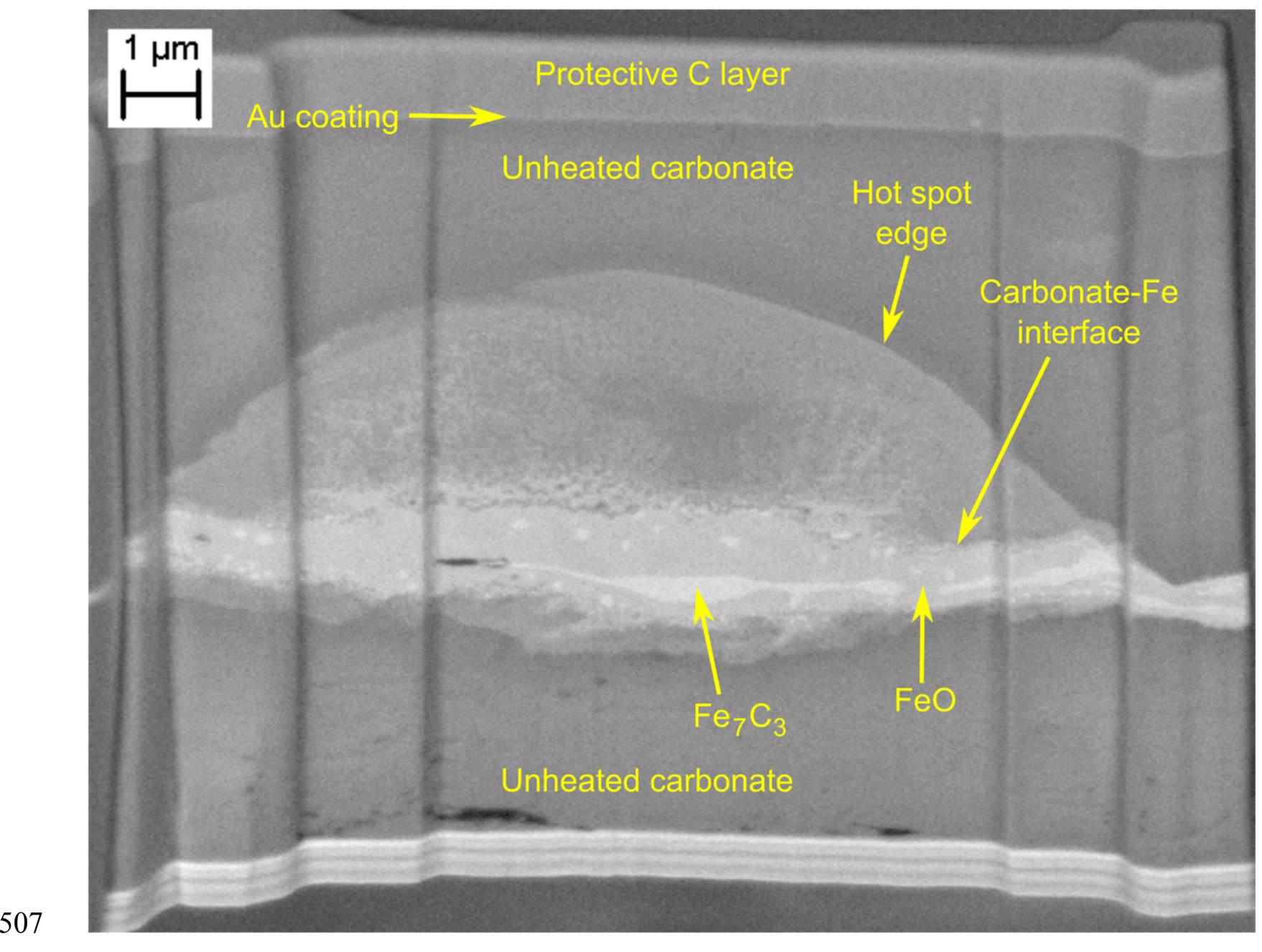

508 Figure 1: Backscattered scanning electron image recorded at $4 \mathrm{kV}$ of dolomite-iron reaction

509 interface in sample thin section recovered from $66 \mathrm{GPa}$ and 1900-2200 K. The iron-rich region in

510 the center appears brightest due to its high density. The extent of iron diffusion into and reaction

511 with the Fe-poor carbonate is also evident based on density. A few micron offset in alignment of

512 upstream and downstream lasers may be responsible for asymmetry of heated spot. 


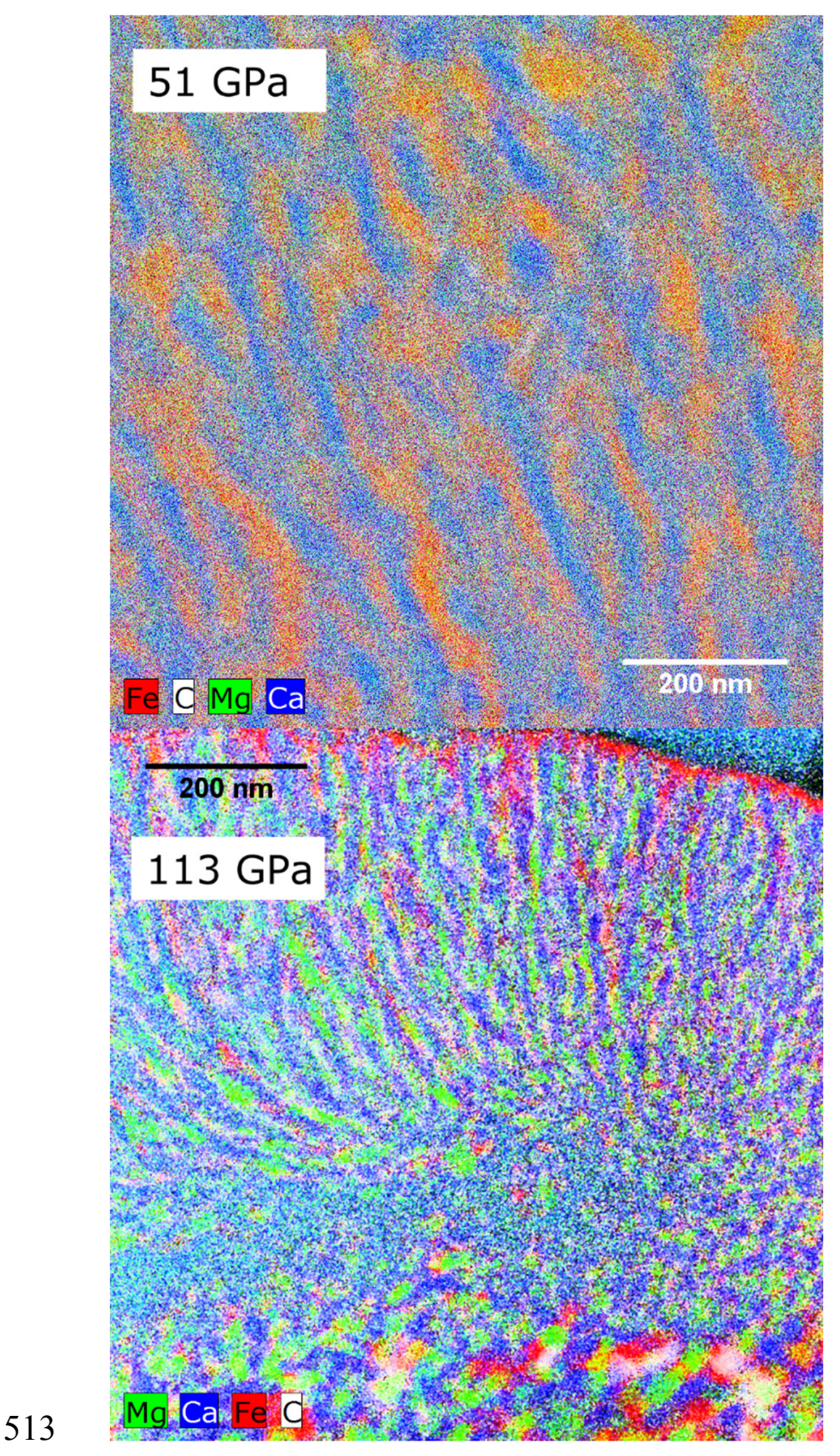

514 Figure 2: Energy-dispersive X-ray image of a) exsolution of two carbonates from dolomite at 51

$515 \mathrm{GPa}$ and $\mathrm{b}$ ) formation of $\mathrm{Fp}+\mathrm{C}+\mathrm{CaCO}_{3}$ at $113 \mathrm{GPa}$. Elements color-coded as follows:

516 red=iron, blue=calcium, green=magnesium, white=carbon. 

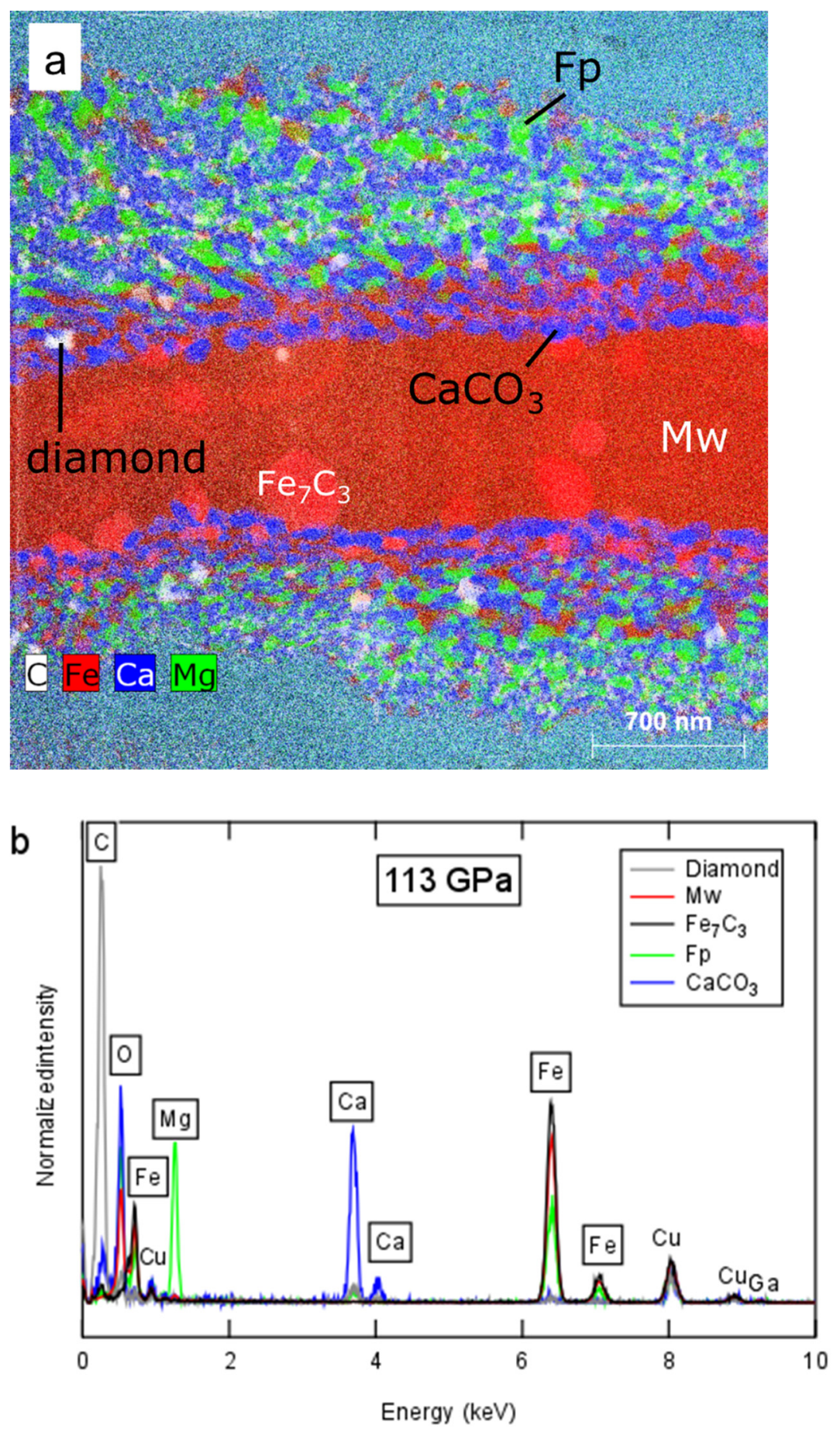

520 Figure 3: Composition measurements for dolomite-iron sample recovered from $113 \mathrm{GPa}$ and

$5212400-2500$ K. a) Energy-dispersive X-ray map with elements color-coded as follows: red=iron, 
522 blue $=$ calcium, green=magnesium, white $=$ carbon. b) Examples of EDX spectra obtained for each 523 phase. 

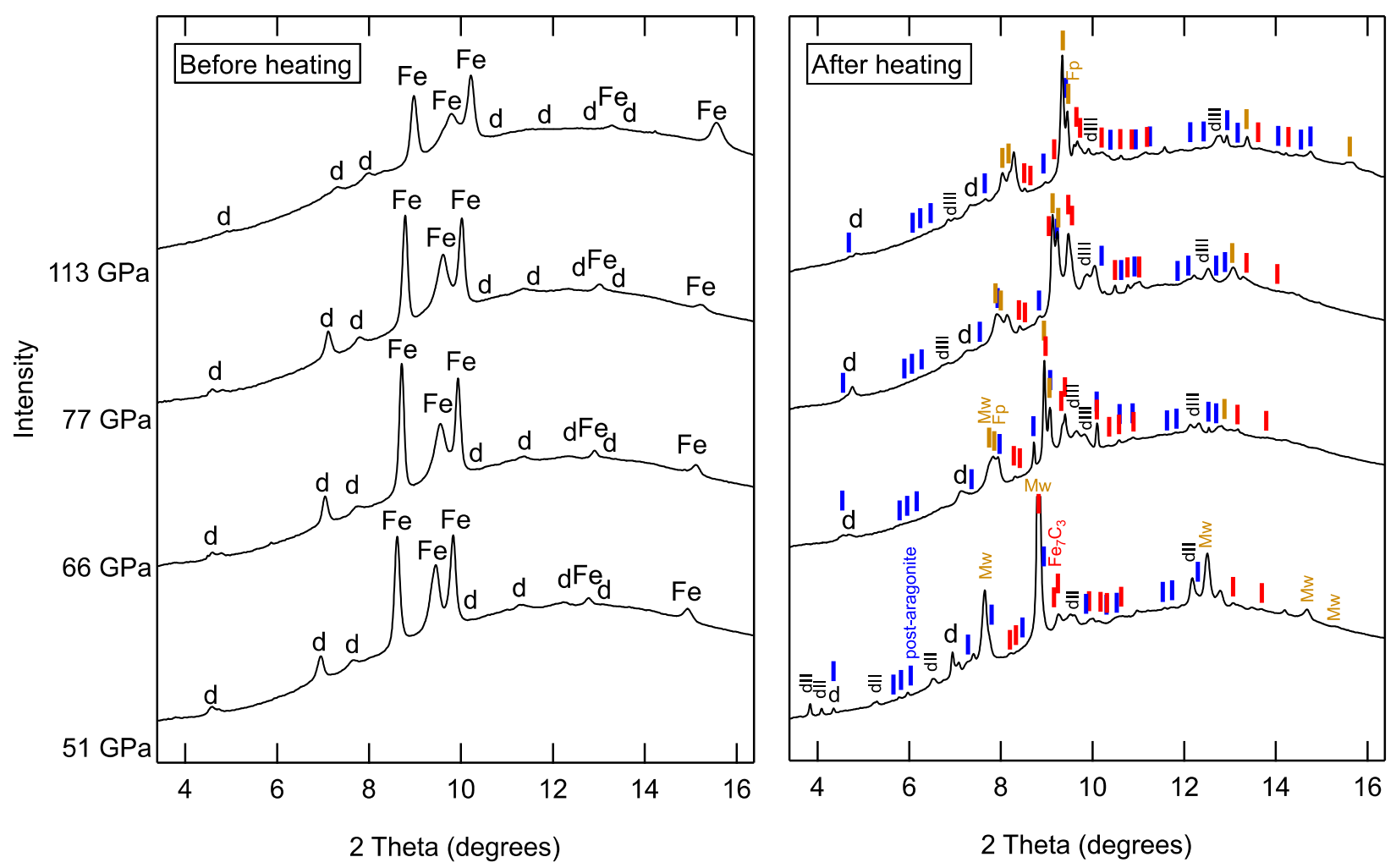

525 Figure 4: X-ray diffraction patterns observed before and after transforming samples of dolomite

526 (d) and iron foil (Fe) to magnesiowüstite and ferropericlase (gold $\mathrm{Mw}$ and $\mathrm{Fp}$ ), $\mathrm{Fe}_{7} \mathrm{C}_{3}$ (red), and 527 post-aragonite-type $\mathrm{CaCO}_{3}$ (blue) at pressures $51-113 \mathrm{GPa}$ and temperatures $1800-2500 \mathrm{~K}$ in the 
528 laser-heated diamond anvil cell. Additional diffraction peaks from high-pressure polymorphs of

529 dolomite are labelled dII and dIII. For these experiments $\lambda=0.3100 \AA$.

530
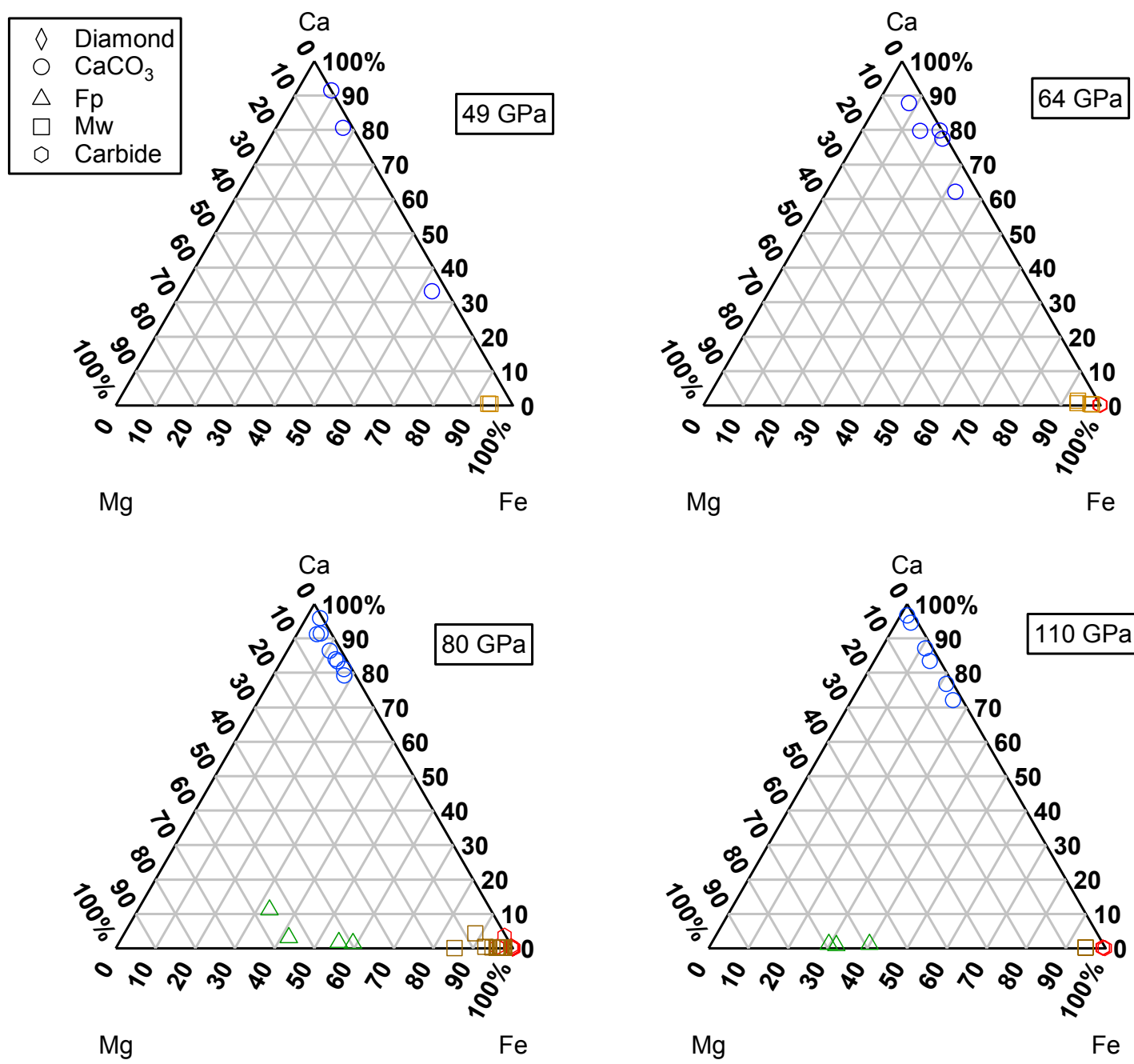

531

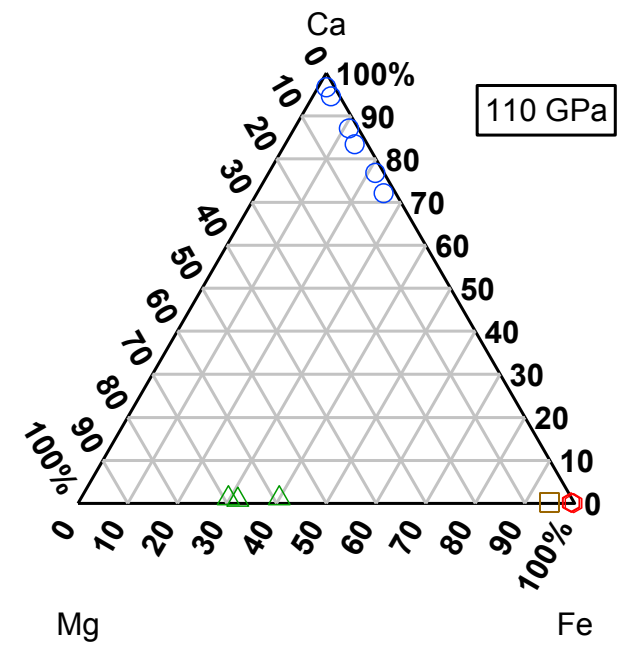

532 Figure 5: Compositions for observed phases obtained from EDX spectra plotted on $\mathrm{Mg}-\mathrm{Fe}-\mathrm{Ca}$

533 ternary diagrams. 


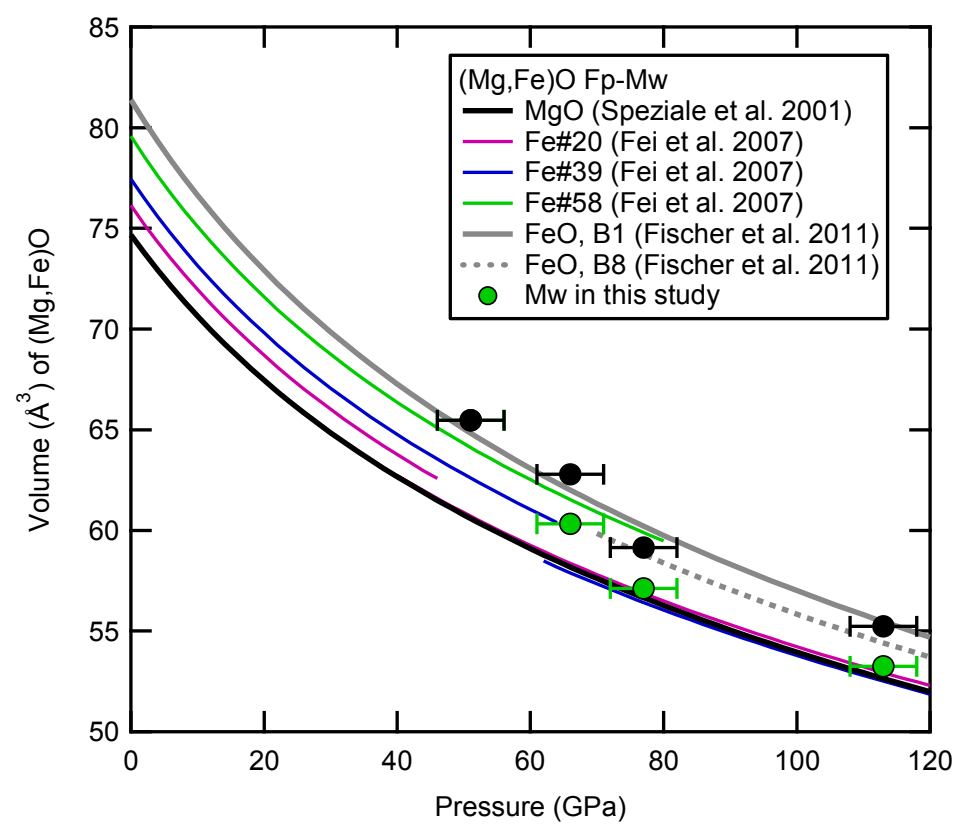

536 Figure 6: Observed unit cell volumes for Mw (black) and Fp (green) in this study plotted relative

537 to previously-measured equations of state for Fp-Mw compositions with different

538 Fe\#=Fe/(Mg+Fe) (Fei et al., 2007; Fischer et al., 2011; Speziale et al., 2001). Pressures for data

539 in this study are assumed to be the same as pressures obtained from the Fe foil before heating.

$540(\mathrm{Mg}, \mathrm{Fe}) \mathrm{O}$ diffraction peaks are split, indicating unit cell volumes consistent with coexistence of

$541 \mathrm{FeO}$ at the sample center and $\sim\left(\mathrm{Mg}_{0.6} \mathrm{Fe}_{0.4}\right) \mathrm{O}$ produced by breakdown of the dolomite. A

542 decrease in unit cell volume observed in both oxides between 66 and $77 \mathrm{GPa}$ is consistent with

543 the spin transition in iron-rich Mw and structural change in FeO under these conditions. 
545 Table 1.

546 Pressure, temperature, and heating duration for all experiments. Pressures given were obtained

547 before heating from the equation of state of the iron foil (Mao et al., 1990). Temperature

548 differences between downstream and upstream sides were typically observed to be $\sim 100 \mathrm{~K}$ and

549 varied by $\sim 100 \mathrm{~K}$ over the heating duration.

\begin{tabular}{|c|c|c|c|}
\hline $\begin{array}{l}\text { Pressure before heating } \\
(\mathrm{GPa})\end{array}$ & Temperature $(\mathrm{K})$ & Duration (min) & $\begin{array}{l}550 \\
551\end{array}$ \\
\hline 51 & $1800-2050$ & 15 & \\
\hline 66 & $1900-2200$ & 10 & \\
\hline 77 & $1900-2200$ & 20 & \\
\hline 113 & $2400-2500$ & 10 & \\
\hline
\end{tabular}

